Research Article

\title{
Total Phenolic, Flavonoid Contents, and Antioxidant Activities of Fruit, Seed, and Bark Extracts of Zanthoxylum armatum DC
}

\author{
Nirmala Phuyal $\mathbb{D}^{1,2}$ Pramod Kumar Jha, ${ }^{1}$ Pankaj Prasad Raturi, ${ }^{3}$ \\ and Sangeeta Rajbhandary ${ }^{1}$ \\ ${ }^{1}$ Central Department of Botany, Tribhuvan University, Kirtipur, Kathmandu, Nepal \\ ${ }^{2}$ Forest Research and Training Centre, Ministry of Forests and Environment, Babarmahal, Kathmandu, Nepal \\ ${ }^{3}$ Ashok Medicinal and Aromatic Plants Center, Dabur Nepal Pvt. Ltd., Janagal, Kavre, Kathmandu, Nepal \\ Correspondence should be addressed to Nirmala Phuyal; nirmalaphuyal@gmail.com
}

Received 12 January 2020; Revised 31 January 2020; Accepted 17 February 2020; Published 16 March 2020

Academic Editor: Maria C. Yebra-Biurrun

Copyright (c) 2020 Nirmala Phuyal et al. This is an open access article distributed under the Creative Commons Attribution License, which permits unrestricted use, distribution, and reproduction in any medium, provided the original work is properly cited.

Natural antioxidants present in several medicinal plants are responsible for inhibiting the harmful effects of oxidative stress. These plants contain polyphenols and flavonoids that act as free radical scavengers and reduce oxidative stress and may be an alternative remedy to cure various harmful human diseases. This study aims to quantify the total phenolic and flavonoid contents (TPC and TFC) and antioxidant properties of methanol extracts of fruits, seeds, and bark of an important medicinal and aromatic plant, Zanthoxylum armatum collected from wild and cultivated populations in Nepal. TPC was determined by Folin-Ciocalteu colorimetric method using gallic acid as standard, and various concentrations of the extract solutions were measured at $760 \mathrm{~nm}$. TFC was calculated by aluminum chloride colorimetric assay. Quercetin was used as standard, and the absorbance was measured at $510 \mathrm{~nm}$. The antioxidant potential of the different extracts was estimated by DPPH free radical scavenging assay, and the absorbance was measured at $517 \mathrm{~nm}$. The highest TPC value was $226.3 \pm 1.14 \mathrm{mg}$ GAE/g in wild fruits, and the lowest was $137.72 \pm 4.21 \mathrm{mg}$ GAE/g in cultivated seeds. Similarly, the highest TFC value was $135.17 \pm 2.02 \mathrm{mg}$ QE/g in cultivated fruits, and the lowest was $76.58 \pm 4.18 \mathrm{mg} \mathrm{QE} / \mathrm{g}$ in cultivated seeds. The extracts showed variable antioxidant properties. The fruits exhibited excellent antioxidant properties with $\mathrm{IC}_{50} \mathrm{values}$ of $40.62 \mu \mathrm{g} / \mathrm{mL}$ and $45.62 \mu \mathrm{g} / \mathrm{mL}$ for cultivated and wild fruits, respectively. Similarly, the $\mathrm{IC}_{50}$ values of the bark were $63.39 \mu \mathrm{g} / \mathrm{mL}$ and $67.82 \mu \mathrm{g} / \mathrm{mL}$, respectively, for cultivated and wild samples. And the least antioxidant capacity was shown by the seeds extract with $\mathrm{IC}_{50}$ values of $86.75 \mu \mathrm{g} / \mathrm{mL}$ and $94.49 \mu \mathrm{g} / \mathrm{mL}$ for wild and cultivated seeds, respectively. The $\mathrm{IC}_{50}$ value of the standard ascorbic acid was $36.22 \mu \mathrm{g} / \mathrm{mL}$. Different extracts of $Z$. armatum contain considerable amount of phenols and flavonoids, including antioxidant properties, suggesting the potential use of this species in pharmacy and phytotherapy as a source of natural antioxidants.

\section{Introduction}

Medicinal plants have been used in several indigenous herbal practices since very old times to cure several diseases. Herbal medication still continues to serve as an important health care system even today despite the greater advancements in modern medication systems in the recent years. Their long uses in the folk medicine and their safer implications in human health have generated much interest in them, especially in developing countries. It has now been established that medicines derived from plant products are safer than their synthetic counterparts [1].
Plant and plant-based products are the natural sources of different phytochemicals such as phenols, flavonoids, alkaloids, glycosides, lignins, and tannins. Phenols and flavonoids are the most common phytoconstituents of different fruits, vegetables, and medicinal and aromatic plants, which are responsible for antioxidant activities [2]. Due to the potential toxicological effects of synthetic antioxidants [3], natural antioxidants such as phenols and flavonoid compounds from plant origin are gaining popularity these days [4]. An antioxidant is a substance that inhibit or delays oxidative damage to the cells of the organisms by scavenging the free radicals such as peroxide or hydroperoxide and thus reducing the risk 
of degenerative diseases [5]. Abnormal production of free radicals may cause several severe human diseases such as cancer; Alzheimer's disease; cardiac, kidney, and liver diseases; fibrosis; atherosclerosis; arthritis; neurodegenerative disorders; and aging. Several medicinal plants have been screened for their antioxidant and other biological activities [6-8].

Zanthoxylum armatum DC (family: Rutaceae), commonly called as Timur in Nepal, is an aromatic perennial shrub or a small tree up to $6 \mathrm{~m}$ height with dense glabrous foliage and straight prickles. It is distributed from Kashmir to Bhutan, north-east India and Pakistan, Laos, Myanmar, Thailand, China, Japan, North and South Korea, North Vietnam, and Taiwan [9]. In Nepal, it is found at $1000 \mathrm{~m}$ to $2500 \mathrm{~m}$ from east to west [10]. It is used in traditional medicinal systems for various ailments such as cholera, diabetes, cough, diarrhea, fever, headache, microbial infections, and toothache [11-14]. The dried fruits of the plant are used as condiment and have excellent spice value. Several phytocomponents such as alkaloids, flavonoids, terpenoids, phenols, and steroids have been extracted from different parts of the plant such as fruits, seeds, leaves, and bark $[13,15,16]$. These compounds are responsible for several pharmacological activities such as antibacterial, antifungal and antihelminthic, antioxidant, anti-inflammatory, hepatoprotective, cytotoxic, larvicidal, and antispasmodic [17-21].

A lot of experiments have been carried out in $Z$. armatum regarding their antioxidant properties [22]. But the comparative study from different habitats and different parts of the plants is still meager, so the present study was carried out to quantify the total phenolic and flavonoid contents and evaluate the antioxidant properties in methanolic extracts of the fruits, seeds, and bark of $Z$. armatum collected from wild and cultivated populations. The correlation between total phenolic and flavonoid content and antioxidant activity with the habitat conditions could help to establish foundation for further studies focusing on the development of safer and inexpensive natural antioxidants for their use in therapeutic and pharmaceutical preparations.

\section{Methods}

2.1. Collection and Processing of Samples. The fresh fruits, seeds, and bark of $Z$. armatum were collected from wild and cultivated populations from Salyan district of west Nepal during May 2018. The plants were collected with the permission of Department of Plant Resources, Ministry of Forests and Environment, Government of Nepal, in accordance with article no. 10(B) of Plant Resource Research Procedure 2013 and revised 2016. This plant is not mentioned in CITES and protected plant list of Nepal. The plant was identified by Nirmala Phuyal. Herbarium of voucher specimens was prepared and deposited at National Herbarium and Plant Laboratories (KATH); NPZA 20-NPZA 50. The samples were cleaned and shade dried for a week before the extraction procedure.

2.2. Extraction of the Samples. The dried samples were then powdered separately in a grinder. Known weight of the powdered samples was loaded in thimble and put inside the
Soxhlet apparatus. They were then successively extracted with methanol by the hot Soxhlet extraction method. The apparatus was run for 72 hours till the colored solvent appeared in the siphon for obtaining the crude extracts of the samples. After complete extraction, the solvent was evaporated in a rotary vacuum evaporator at $65^{\circ} \mathrm{C}$ under reduced pressure. The obtained extracts were then dried in a water bath. The dried extracts were sealed inside $20 \mathrm{~mL}$ sterilized culture tubes and stored in refrigerator at $2-8^{\circ} \mathrm{C}$ for further analysis [23].

\subsection{Determination of Total Phenolic Content (TPC)}

2.3.1. Preparation of Standard Gallic Acid for Calibration Curve. Total phenolic contents (TPC) in the fruits, seeds, and bark extracts were determined by Folin-Ciocalteu colorimetric method as described by Singleton et al. [24] with some modifications. Standard gallic acid solution was prepared by dissolving $10 \mathrm{mg}$ of it in $10 \mathrm{~mL}$ of methanol $(1 \mathrm{mg} / \mathrm{mL})$. Various concentrations of gallic acid solutions in methanol $(25,50,75$, and $100 \mu \mathrm{g} / \mathrm{mL})$ were prepared from the standard solution. To each concentration, $5 \mathrm{~mL}$ of $10 \%$ Folin-Ciocalteu reagent (FCR) and $4 \mathrm{~mL}$ of $7 \% \mathrm{Na}_{2} \mathrm{CO}_{3}$ were added making a final volume of $10 \mathrm{~mL}$. Thus, the obtained blue colored mixture was shaken well and incubated for $30 \mathrm{~min}$ at $40^{\circ} \mathrm{C}$ in a water bath. Then, the absorbance was measured at $760 \mathrm{~nm}$ against blank. The FCR reagent oxidizes phenols in plant extracts and changes into the dark blue color, which is then measured by UV-visible spectrophotometer. All the experiments were carried out in triplicates, and the average absorbance values obtained at different concentrations of gallic acid were used to plot the calibration curve.

\subsubsection{Preparation of Samples for Total Phenolic Content.} Various concentrations of the extracts $(25,50,75$, and $100 \mu \mathrm{g} / \mathrm{mL}$ ) were prepared. The procedure as described for standard gallic acid was followed, and absorbance for each concentration of the extracts was recorded. The samples were prepared in triplicate for each analysis, and the average value of absorbance was used to plot the calibration curve to determine the level of phenolics in the extracts. Total phenolic content of the extracts was expressed as mg gallic acid equivalents (GAE) per gram of sample in dry weight $(\mathrm{mg} / \mathrm{g})$. The total phenolic contents in all the samples were calculated by the using the formula:

$$
C=c \frac{V}{m}
$$

where $C=$ total phenolic content $\mathrm{mg}$ GAE/g dry extract, $c=$ concentration of gallic acid obtained from calibration curve in $\mathrm{mg} / \mathrm{mL}, V=$ volume of extract in $\mathrm{mL}$, and $m=$ mass of extract in gram.

\subsection{Determination of Total Flavonoid Content}

2.4.1. Preparation of Standard Quercetin for Calibration Curve. Total flavonoid contents in the extracts were 
determined by aluminum chloride colorimetric assay. Stock solution $(4 \mathrm{mg} / \mathrm{mL})$ of quercetin was prepared by dissolving $4 \mathrm{mg}$ of quercetin in $1 \mathrm{~mL}$ of methanol. This standard solution was diluted serially to make various concentrations of $0.25 \mathrm{mg} / \mathrm{mL}, 0.5 \mathrm{mg} / \mathrm{mL}, 0.75 \mathrm{mg} / \mathrm{mL}$, and $1 \mathrm{mg} / \mathrm{mL}$ solutions. $1 \mathrm{~mL}$ quercetin of each concentration was added to the test tube containing $4 \mathrm{~mL}$ of distilled water. At the same time, $0.3 \mathrm{~mL}$ of $5 \% \mathrm{NaNO}_{2}$ was added to the test tube and $0.3 \mathrm{~mL}$ of $10 \% \mathrm{AlCl}_{3}$ after $5 \mathrm{~min}$. Then, $2 \mathrm{~mL}$ of $1 \mathrm{M} \mathrm{NaOH}$ was added to the mixture after $6 \mathrm{~min}$. The volume of the mixture was made $10 \mathrm{~mL}$ by immediately adding $4.4 \mathrm{~mL}$ of distilled water. The total flavonoids content was expressed as quercetin equivalents using the linear equation based on the calibration curve.

2.4.2. Preparation of Samples for Total Flavonoid Content. Stock solutions of $4 \mathrm{mg} / \mathrm{mL}$ concentration in methanol of the extracts were prepared, and they were diluted serially to make different concentrations $(0.25 \mathrm{mg} / \mathrm{mL}, 0.5 \mathrm{mg} / \mathrm{mL}$, $0.75 \mathrm{mg} / \mathrm{mL}$, and $1 \mathrm{mg} / \mathrm{mL}$ ) solutions. Similar procedure as described for quercetin was followed for the extracts also, and the absorbance was measured by spectrophotometer at $510 \mathrm{~nm}$. Readings were taken in triplicate, and the average value of absorbance was used to calculate the total flavonoid content. The flavonoid content was expressed as quercetin equivalent (mg QE/g) using the linear equation based on the standard calibration curve.

\subsection{Antioxidant Activities}

2.5.1. DPPH (2,2-Diphenyl-1-picrylhydrazyl) Radical Scavenging Activity. In vitro antioxidant activities of the extracts were determined using the DPPH free radical scavenging assay described by Nithianantham et al. [25] with some modifications. This is a quick and easy method to analyze the scavenging potential of antioxidants. DPPH in oxidized form gives a deep violet color in methanol. An antioxidant compound donates the electron to $\mathrm{DPPH}$, thus causing its reduction and in reduced form its color changes from deep violet to yellow. DPPH solutions show a strong absorbance at $517 \mathrm{~nm}$ appearing as deep violet color. Scavenging of DPPH free radical determines the free radical scavenging capacity or antioxidants potential of the test samples, which shows its effectiveness, prevention, interception, and repair mechanism against injury in a biological system.

2.5.2. Preparation of DPPH Solution (0.1 M). DPPH solution $(0.1 \mathrm{M})$ was prepared by dissolving $0.39 \mathrm{mg}$ of DPPH in a volumetric flask, dissolved in methanol, and the final volume was made $100 \mathrm{~mL}$. Thus, prepared purple-colored DPPH free radical solution was stored at $-20^{\circ} \mathrm{C}$ for further use.

2.5.3. Preparation of Extract Solutions. Stock solution of different extracts of $1 \mathrm{mg} / \mathrm{mL}$ was prepared by dissolving required quantity of each extract in required volume of methanol. From the sample stock solution, 25, 50, 75, and $100 \mu \mathrm{g} / \mathrm{mL}$ solutions of each extract were prepared.
2.6. Evaluation of Antioxidant Potential. To the sample solutions of different concentration, $1 \mathrm{~mL}$ DPPH solution was added and incubated at room temperature for $30 \mathrm{~min}$ in dark. A control was prepared by mixing $1 \mathrm{~mL}$ methanol and $1 \mathrm{~mL}$ DPPH solution. Finally, the absorbance of the solutions was measured by using a spectrophotometer at $517 \mathrm{~nm}$. Ascorbic acid was used as the standard. 50\% inhibitory concentrations ( $\mathrm{IC}_{50}$ values) of the extracts were calculated from graph as concentration versus percentage inhibition. Radical scavenging activity was expressed as percentage of inhibition. $\mathrm{IC}_{50}$ value is the concentration of sample required to scavenge $50 \%$ of DPPH free radical. Measurements were taken in triplicate. $\mathrm{IC}_{50}$ of the extracts indicates the corresponding concentration in which the radical scavenging potential is $50 \%$. The $\mathrm{IC}_{50}$ of the extract and standards were determined graphically.

The percentage of inhibition was calculated by using the formula:

$$
\mathrm{I} \%=\frac{\mathrm{AC}-\mathrm{AO}}{\mathrm{AC}} \times 100 \%,
$$

where $\mathrm{AC}=$ absorbance of the control $(1 \mathrm{~mL}$ methanol $+1 \mathrm{~mL}$ DPPH solution), $\mathrm{AO}=$ absorbance of the sample solution, and $\mathrm{I} \%=$ percentage of inhibition.

The radical scavenging activities of the extracts are expressed in terms of their $\mathrm{IC}_{50}$ values. The data were presented as mean values \pm standard deviation $(n=3)$.

\section{Results}

3.1. Total Phenolic Contents (TPC). Total phenolic contents in different extracts of fruits, seeds, and bark of $Z$. armatum were determined by Folin-Ciocalteu (F-C) method using gallic acid as the standard. The absorbance values obtained at different concentrations of gallic acid were used for the construction of calibration curve. Total phenolic content of the extracts was calculated from the regression equation of calibration curve $\left(Y=0.0108 x ; R^{2}=0.993\right)$ and expressed as mg gallic acid equivalents (GAE) per gram of sample in dry weight $(\mathrm{mg} / \mathrm{g})$.

TPC values were higher in the fruit and bark extracts than the seed extracts. The highest TPC value was observed for the fruits followed by the bark, and the lowest was for the seeds extracts. TPC value of the cultivated fruit extract was $226.3 \pm 1.14 \mathrm{mg} \mathrm{GAE} / \mathrm{g}$ and that for wild fruit was $185.02 \pm 2.15 \mathrm{mg}$ GAE/g. Similarly, the value was $185.15 \pm 1.22 \mathrm{mg} \mathrm{GAE} / \mathrm{g}$ for wild bark and $171.13 \mathrm{mg} \mathrm{GAE} / \mathrm{g}$ for cultivated bark. And for the wild seeds, the TPC value was $167.74 \pm 2.63 \mathrm{mg} \mathrm{GAE} / \mathrm{g}$ and that for cultivated was $137.72 \pm 4.21 \mathrm{mg} \mathrm{GAE} / \mathrm{g}$ (Table 1 ).

This is in accordance with the study of Barkatullah et al. [18], where the TPC value of ethanolic extracts of $Z$. armatum fruits was found to be $21.68 \pm 0.44 \mathrm{mg} / \mathrm{g}$ and that of the bark was $16.48 \pm 1.33 \mathrm{mg} / \mathrm{g}$. Similarly, in another study, the TPC value of methanol extract of fruits was $366.3 \mathrm{mg}$ of GAE/g [19]. The phenolic content of any plants is directly related to their antioxidant properties. Phenolic compounds act as reducing agents, hydrogen donors, and are capable of scavenging free radicals [26]. Presence of considerably good 
TABLE 1: Total phenolic contents (TPC) in different extracts of $Z$. armatum.

\begin{tabular}{lcccccc}
\hline S. No. & Samples & $25(\mu \mathrm{g} / \mathrm{mL})$ & $50(\mu \mathrm{g} / \mathrm{mL})$ & $75(\mu \mathrm{g} / \mathrm{mL})$ & $100(\mu \mathrm{g} / \mathrm{mL})$ & Mean TPC value $(\mathrm{GAE} / \mathrm{g})$ \\
\hline 1 & Fruits (wild) & 181.48 & 185.18 & 186.41 & 187.03 & $185.02 \pm 2.15$ \\
2 & Fruits (cultivated) & 225.92 & 227.77 & 224.69 & 226.85 & $226.3 \pm 1.14$ \\
3 & Seeds (wild) & 166.66 & 166.66 & 165.43 & 172.22 & $167.74 \pm 2.63$ \\
4 & Seeds (cultivated) & 133.33 & 135.18 & 144.44 & 137.96 & $137.72 \pm 4.21$ \\
5 & Bark (wild) & 184.77 & 183.33 & 186.41 & 186.11 & $185.15 \pm 1.22$ \\
6 & Bark (cultivated) & 162.93 & 168.51 & 171.6 & 181.48 & $171.13 \pm 6.73$ \\
\hline
\end{tabular}

amount of phenolics in the fruits, seeds, and bark extracts of $Z$. armatum may contribute significantly to the antioxidant properties. Because of these properties, this plant might have been used in several traditional herbal medications.

The antioxidant response of phenolic compounds varies remarkably, depending on their chemical structure [27]. In addition, there may be some interference rising from other chemical components present in the extract, such as sugars or ascorbic acid [28]. In this study also, there were differences in the total phenolic components of the wild and cultivated fruits, seeds, and bark extracts. These differences could arise from variations in genetic backgrounds, environmental factors, agronomic practices as well [29].

3.2. Total Flavonoid Contents (TFC). Total flavonoid content of the extracts was calculated from the regression equation of the calibration curve $\left(Y=0.0011 x ; R^{2}=0.992\right)$ and expressed as mg quercetin equivalents (QE) per gram of sample in dry weight $(\mathrm{mg} / \mathrm{g})$. The TFC values also showed similar trends with that of TPC values. The highest TFC value was obtained for the fruits followed by the bark, and the lowest was for the seeds extracts. The highest TFC value was $135.17 \pm 2.02 \mathrm{mg}$ $\mathrm{QE} / \mathrm{g}$ for cultivated fruit extract, and for wild fruit, it was $103.7 \pm 1.39 \mathrm{mg} \mathrm{QE} / \mathrm{g}$. The TFC values were $111.2 \pm 3.67 \mathrm{mg}$ $\mathrm{QE} / \mathrm{g}$ and $91.27 \pm 3.13 \mathrm{mg} \mathrm{QE} / \mathrm{g}$ for cultivated and wild barks, respectively. Similarly, the lowest TFC value was $76.58 \pm 4.18 \mathrm{mg} \mathrm{QE} / \mathrm{g}$ for cultivated seeds, and for wild seeds, it was $92.71 \pm 3.14 \mathrm{mg} \mathrm{QE} / \mathrm{g}$ (Table 2). In a previous study, the total flavonoid content of ethanolic extracts of $Z$. armatum fruit was $22.8 \pm 1.33 \mathrm{mg} / \mathrm{g}$ and that of bark was $18.33 \pm 1.22 \mathrm{mg} / \mathrm{g}$ [18], which is quite lower than that of the present study. The concentration of phenols and flavonoids also depends on the polarity of the solvents used for extraction [30].

\subsection{Antioxidant Activity}

3.3.1. DPPH Assay. Antioxidant activity of the fruits, seeds, and bark of $Z$. armatum was determined by DPPH free radical scavenging assay, and their reducing power was determined on the basis of their concentration providing $50 \%$ inhibition $\left(\mathrm{IC}_{50}\right)$ values or in other words, the amount required to scavenge $50 \% \mathrm{DPPH}$ free radicals. The mean percentage of DPPH free-radical scavenging activity at different concentrations of extracts is shown in Table 3, Figure 1 . The radical scavenging activity of different extracts increased in a concentration dependent manner.
Ascorbic acid used as the standard and the different extracts showed variable antioxidant properties. The $\mathrm{IC}_{50}$ value of ascorbic acid was $36.22 \mu \mathrm{g} / \mathrm{mL}$. The higher $\mathrm{IC}_{50}$ value indicates lower radical scavenging activity or lower antioxidant potential. The fruits extracts had the highest antioxidant capacity compared to the seeds and bark extracts. The $\mathrm{IC}_{50}$ value of the fruits extracts was close to that of the standard, i.e., $40.62 \mu \mathrm{g} / \mathrm{mL}$ and $45.62 \mu \mathrm{g} / \mathrm{mL}$, respectively, for the cultivated and wild fruits. Similarly, the $\mathrm{IC}_{50}$ value was $86.75 \mu \mathrm{g} / \mathrm{mL}$ and $94.49 \mu \mathrm{g} / \mathrm{mL}$, respectively, for wild and cultivated seeds, showing least antioxidant properties. And the bark showed moderate antioxidant capacity with the $\mathrm{IC}_{50}$ value of $63.39 \mu \mathrm{g} / \mathrm{mL}$ and $67.82 \mu \mathrm{g} / \mathrm{mL}$ for cultivated and wild extracts, respectively. The antioxidant potential of fruits and bark extracts were higher in cultivated than in wild samples, whereas in seeds extracts, it was higher in wild than cultivated samples.

The antioxidant potential of different parts of Zanthoxylum armatum has been evaluated by various previous studies [20, 31-35]. The free radical scavenging activity of methanolic fruits extracts ranged from 59.56 to $64.85 \%$ [36], while in the present study, the scavenging percent ranged from 58.35 to $78.36 \%$ (Table 3 ). Similarly, the $\mathrm{IC}_{50}$ value of the methanolic bark extract of $Z$. armatum was $149.26 \mu \mathrm{g} /$ $\mathrm{mL}$ [34], but it was $63.39 \mu \mathrm{g} / \mathrm{mL}$ in the present study.

The radical scavenging activity of different extracts of $Z$. armatum may be due to the presence of polyphenols, flavonoids, and phenolic compounds, and most of the antioxidant activity of plants is because of the phenols [37]. Natural antioxidants present in plants are responsible for inhibiting or preventing the harmful consequences of oxidative stress. DPPH assay among many other assays is one of the convenient methods for determining the antioxidant potential of plants. The presence of antioxidant substances containing hydrogen-donating groups such as flavonoids and phenols causes the methanolic DPPH solution to get reduced due to the formation of nonradical [38]. Apart from antioxidant properties, flavonoids and other phenolics also exhibit several biological activities such as antimicrobial, antiviral, and anticancer [39]. These biological and pharmacological activities are usually associated with their ability of binding proteins and free radical scavenging properties [40].

Antioxidants are tremendously important substances, which possess the ability to protect the body from damage caused by free radical-induced oxidative stress. Plant polyphenols act as reducing agents and antioxidants by the hydrogen-donating property of their hydroxyl groups [41]. 
TABLE 2: Total flavonoid contents (TFC) in different extracts of Z. armatum.

\begin{tabular}{lcccccc}
\hline S. No. & Samples & $0.25 \mathrm{mg} / \mathrm{mL}$ & $0.50 \mathrm{mg} / \mathrm{mL}$ & $0.75 \mathrm{mg} / \mathrm{mL}$ & $1 \mathrm{mg} / \mathrm{mL}$ & Mean TFC value $(\mathrm{QE} / \mathrm{g})$ \\
\hline 1 & Fruits (wild) & 101.8 & 105.44 & 103.02 & 104.54 & $103.7 \pm 1.39$ \\
2 & Fruits (cultivated) & 138.16 & 134.54 & 132.54 & 135.45 & $135.17 \pm 2.02$ \\
3 & Seeds (wild) & 94.52 & 94.54 & 87.26 & 94.54 & $92.71 \pm 3.14$ \\
4 & Seeds (cultivated) & 72.72 & 74.54 & 83.62 & 75.45 & $76.58 \pm 4.18$ \\
5 & Bark (wild) & 90.88 & 94.54 & 93.33 & 86.36 & $91.27 \pm 3.13$ \\
6 & Bark (cultivated) & 116.36 & 109.08 & 106.66 & 112.72 & $111.2 \pm 3.67$ \\
\hline
\end{tabular}

TABLE 3: Mean absorbance and $\mathrm{IC}_{50}$ values of extract and ascorbic acid at different concentrations.

\begin{tabular}{lccccccc}
\hline \multicolumn{7}{c}{ \% Inhibition (scavenging capacity) } & \\
Concentration $(\mu \mathrm{g} / \mathrm{mL})$ & Ascorbic acid & Fruits (wild) & Fruits (cultivated) & Seeds (wild) & Seeds (cultivated) & Bark (wild) & Bark (cultivated) \\
\hline 100 & 84.21 & 73.29 & 78.36 & 49.41 & 46.44 & 58.45 & 61.25 \\
75 & 78.22 & 68.2 & 73.54 & 44.12 & 41.36 & 53.98 & 56.08 \\
50 & 72.45 & 63.84 & 67.38 & 41.47 & 38.98 & 48.67 & 51.12 \\
25 & 65.13 & 58.35 & 62.23 & 37.49 & 34.21 & 43.46 & 46.04 \\
0 & 0 & 0 & 0 & 0 & 0 & 0 & 67.82 \\
$\mathrm{IC}$ & 36.22 & 45.62 & 40.62 & 86.75 & 94.49 & 63.39 \\
\hline
\end{tabular}

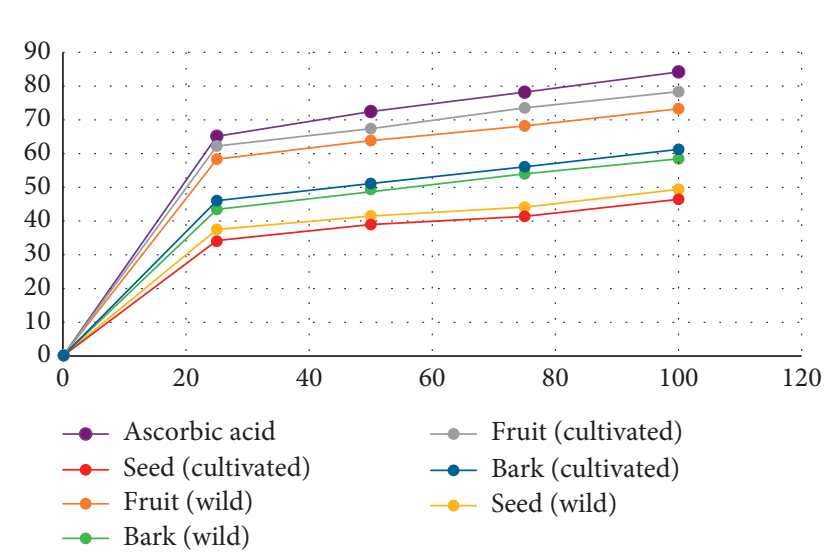

Figure 1: Plot of radical scavenging percentage between ascorbic acid and different samples.

\section{Conclusions}

Total phenolic, flavonoid contents, and antioxidant properties of the fruits, seeds, and bark extracts of $Z$. armatum were considerably good. However, these parameters were remarkably better in fruit and bark extracts as compared to the seed extracts. Some of the wild samples showed excellent results, and some of the cultivated samples showed better results. The differential TPC, TFC contents, and antioxidant properties from different habitat may plausibly be due to geographical variations in chemical constituents. The results of the present study suggested that the fruits, seeds, and bark of $Z$. armatum could be the potent source of natural antioxidants because of their phenolic and flavonoid contents and their remarkable scavenging effects on DPPH. So, this plant could be of greater significance in preventing several harmful human diseases. Further studies should be directed towards the extensive in vivo antioxidant activities of the plant and the relationship of individual phenolic compounds to antioxidant with different mechanisms and isolation, screening, and characterization of individual compounds responsible for antioxidant properties to authenticate their probable uses as sources of natural antioxidants as well as to validate their traditional uses in several medicinal practices.

\section{Data Availability}

All data generated or analyzed during this study are included in this article.

\section{Conflicts of Interest}

The authors declare that they have no conflicts of interest.

\section{Acknowledgments}

We would like to thank Mr. Devi Prasad Bhandari, and Mr. Sumnath Khanal, Department of Plant Resources, for their various help in conducting the experiments. Special thanks to Mr. Krishna Pun from District Plant Resources Office, Salyan, for his great help during field visit. Mr. Sanjeev Kumar Rai, Director General of the Department of Plant Resources, is thankfully acknowledged for his support in carrying out the lab works. Sincere thanks to Prof. Dr. Ram Kailash Prasad Yadav, Head, Central Department of Botany, Tribhuvan University, for his encouragement. This research was partially supported by the grant "Dabur CSR Fellowship (Late Sri Ashok Chand Burman) 01/2016" from Dabur Nepal Private Limited. The funder does not have any role in the overall designing and implementation of this study but one of the coauthors, PPR, is from the funding agency.

\section{References}

[1] K. A. Oluyemi, U. C. Okwuonu, D. G. Baxter, and T. O. Oyesola, "Toxic effects of methanolic exract of Aspilia africana leaf on the estrous cycle and uterine tissues of Wistar rats," International Journal of Morphology, vol. 25, no. 3, pp. 609-614, 2007. 
[2] A. Scalbert, C. Manach, C. Morand, C. Rémésy, and L. Jiménez, "Dietary polyphenols and the prevention of diseases," Critical Reviews in Food Science and Nutrition, vol. 45, no. 4, pp. 287-306, 2005.

[3] J. Liu, L. Jia, J. Kan, and C.-H. Jin, "In vitro and in vivo antioxidant activity of ethanolic extract of white button mushroom (Agaricus bisporus)," Food and Chemical Toxicology, vol. 51, pp. 310-316, 2013.

[4] R.-z. Zhong and D.-w. Zhou, "Oxidative stress and role of natural plant derived antioxidants in animal reproduction," Journal of Integrative Agriculture, vol. 12, no. 10, pp. 18261838, 2013.

[5] S.-i. Yamagishi and T. Matsui, "Nitric oxide, a Janus-faced therapeutic target for diabetic microangiopathy-friend or foe?” Pharmacological Research, vol. 64, no. 3, pp. 187-194, 2011.

[6] R. K. Upadhyay, P. Dwivedi, and S. Ahmad, "Screening of antibacterial activity of six plant essential oils against pathogenic bacterial strains," Asian Journal of Medical Sciences, vol. 2, pp. 152-158, 2010.

[7] K. W. Martin and E. Ernst, "Herbal medicines for treatment of bacterial infections: a review of controlled clinical trials," Journal of Antimicrobial Chemotherapy, vol. 51, no. 2, pp. 241-246, 2003.

[8] B. Mahesh and S. Satish, "Antimicrobial activity of some important medicinal plant against plant and human pathogens," World Journal of Agricultural Sciences, vol. 4, pp. 839-843, 2008.

[9] K. N. Nair and M. P. Nayar, "Flora of India," in MalpighiceaeDichapetalaceae, P. K. Hajra, V. J. Nair, and P. Daniel, Eds., vol. 4, pp. 179-180, Botanical Survey of India, Calcutta, India, 1997.

[10] DPR, Medicinal plants of Nepal (Revised Edition), Vol. 28, Bulletin of Department of Medicinal Plants, Department of Plant Resources, Ministry of Forests and Soil Conservation, Government of Nepal, Kathmandu, Nepal, 2007.

[11] N. K. Kalia, B. Singh, and R. P. Sood, "A new amide from Zanthoxylum armatum," Journal of Natural Products, vol. 62, no. 2, pp. 311-312, 1999.

[12] N. P. Manandhar, Plants and People of Nepal, Timber Press Inc., Portland, OR, USA, 2002.

[13] M. Tiwary, S. N. Naik, D. K. Tewary, P. K. Mittal, and S. Yadav, "Chemical composition and larvicidal activities of the essential oil of Zanthoxylum armatum DC (Rutaceae) against three mosquito vector," Journal of Vector Borne Diseases, vol. 44, no. 3, pp. 198-204, 2007.

[14] N. Verma and R. L. Khosa, "Hepatoprotective activity of leaves of Zanthoxylum armatumDC in $\mathrm{CCl} 4$ induced hepatotoxicity in rats," Indian Journal of Biochemistry \& Biophysics, vol. 47, no. 2, pp. 124-127, 2011.

[15] H. Li, P. Li, L. Zhu, M. Xie, and Z. Wu, "Studies on the chemical constituents of Zanthoxylum armatum DC," ZhongguoYaofang: Chinese Pharmacies, vol. 17, pp. 10351037, 2006.

[16] J. S. Negi, V. K. Bisht, A. K. Bhandari, P. Singh, and R. C. Sundriyah, "Chemical constituents and biological activities of the genus Zanthoxylum: a review," African Journal of Pure and Applied Chemistry, vol. 5, no. 12, pp. 412-416, 2011.

[17] L. Ranawat, J. Bhatt, and J. Patel, "Hepatoprotective activity of ethanolic extracts of bark of Zanthoxylum armatum DC in $\mathrm{CCl} 4$ induced hepatic damage in rats," Journal of Ethnopharmacology, vol. 127, no. 3, pp. 777-780, 2010.
[18] M. Barkatullah, I. Muhammad, N. Muhammad, and T. Lubina, "Antimicrobial evaluation, determination of total phenolic and flavoniod contents in Zanthoxylum armatum DC," Journal of Medicinal Plants Research, vol. 6, no. 11, pp. 2105-2110, 2012.

[19] S. Guleria, A. K. Tiku, A. Koul, S. Gupta, G. Singh, and V. K. Razdan, "Antioxidant and antimicrobial properties of the essential oil and extracts of Zanthoxylum alatum grown in north-western Himalaya," The Scientific World Journal, vol. 2013, Article ID 790580, 9 pages, 2013.

[20] I. Karmakar, S. Haldar, M. Chakraborty, S. Dewanjee, and P. K. Haldar, "Antioxidant and cytotoxic activity of different extracts of Zanthoxylum alatum," Free Radicals and Antioxidants, vol. 5, no. 1, pp. 21-28, 2015.

[21] D. K. Mehta, A. Bhandari, N. K. Sati et al., "Anti-inflammatory activity of methanolic extract of fruit of Zanthoxylum armatum," Inventi Journals Private Limited, vol. 52, p. 11, 2011.

[22] N. Phuyal, P. K. Jha, P. Prasad Raturi, and S. Rajbhandary, "Zanthoxylum armatum DC: current knowledge, gaps and opportunities in Nepal," Journal of Ethnopharmacology, vol. 229, pp. 326-341, 2019.

[23] P. Tiwari, B. Kumar, M. G. Kaur, and H. Kaur, "Phytochemical screening and extraction: a review," International Pharmaceutical Sciences, vol. 1, no. 1, 2011.

[24] V. L. Singleton, R. Orthofer, and R. M. Lamuela-Raventós, "Analysis of total phenols and other oxidation substrates and antioxidants by means of folin-ciocalteu reagent," Oxidants and Antioxidants Part A, vol. 299, pp. 152-178, 1999.

[25] K. Nithianantham, M. Shyamala, Y. Chen, L. Y. Latha, S. L. Jothy, and S. Sasidharan, "Hepatoprotective potential of Clitoria ternatea leaf extract against paracetamol induced damage in mice," Molecules, vol. 16, no. 12, pp. 10134-10145, 2011.

[26] A. Wojdylo, J. Oszmianski, and R. Czemerys, "Antioxidant activity and phenolic compounds in 32 selected herbs," Food Chemistry, vol. 105, no. 3, pp. 940-949, 2007.

[27] S. M. T. Gracia, M. Heinonen, and E. N. Frankel, "Antioxidant activity of anthocyanin in LDL and lecithin liposome systems," Journal of Agricultural and Food Chemistry, vol. 45, pp. 3362-3367, 1997.

[28] V. L. Singleton and J. A. Rossi, "Colorimetry of total phenolics with phosphomolybdic-phosphotungstic acid reagents," American Journal of Enology and Viticulture, vol. 16, pp. 144-158, 1965.

[29] P. Doshi, P. Adsule, and K. Banerjee, "Phenolic composition and antioxidant activity in grapevine parts and berries (Vitis vinifera L.) cv. Kishmish Chornyi (sharad seedless) during maturation," International Journal of Food Science and Technology, vol. 41, no. 1, pp. 1-9, 2006.

[30] L. Jing, H. Ma, P. Fan, R. Gao, and Z. Jia, "Antioxidant potential, total phenolic and total flavonoid contents of Rhododendron anthopogonoides and its protective effect on hypoxia-induced injury in PC12 cells," BMC Complementary and Alternative Medicine, vol. 15, no. 1, p. 287, 2015.

[31] F. Batool, S. M. Sabir, J. B. T. Rocha, A. H. Shah, Z. S. Saify, and S. D. Ahmed, "Evaluation of antioxidant and free radical scavenging activities of fruit extract from Zanthoxylum alatum: a commonly used spice from Pakistan," Pakistan Journal of Botany, vol. 42, no. 6, pp. 4299-4311, 2010.

[32] K. Upadhyaya and A. P. Kumar, "Concentration dependent antioxidant activity of Zanthoxylum armatum," Journal of Pharmacy Research, vol. 3, no. 7, pp. 1581-1582, 2010. 
[33] J. S. Negi, V. K. Bisht, A. K. Bhandari, R. Bisht, and S. Kandari, "Major constituents, antioxidant and antibacterial activities of Zanthoxylum armatum DC., essential oil," Iranian Journal of Pharmacology \& Therapeutics, vol. 11, pp. 68-72, 2012.

[34] M. Mukhijal and A. N. Kalia, "Antioxidant potential and total phenolic content of Zanthoxylum alatum stem bark," Journal of Applied Pharmacy, vol. 6, no. 4, pp. 388-397, 2014.

[35] R. Kanwal, M. Arshad, Y. Bibi, S. Asif, and S. K. Chaudhari, "Evaluation of ethnopharmacological and antioxidant potential of Zanthoxylum armatum DC," Journal of Chemistry, vol. 2015, Article ID 925654, 8 pages, 2015.

[36] Z. Nooreen, S. Singh, D. K. Singh, S. Tandon, A. Ahmad, and S. Luqman, "Characterization and evaluation of bioactive polyphenolic constituents from Zanthoxylum armatum DC., a traditionally used plant," Biomedicine \& Pharmacotherapy, vol. 89, pp. 366-375, 2017.

[37] A. Mansouri, G. Embarek, E. Kokkalou, and P. Kefalas, "Phenolic profile and antioxidant activity of the Algerian ripe date palm fruit (Phoenix dactylifera)," Food Chemistry, vol. 89, no. 3, pp. 411-420, 2005.

[38] L. L. Mensour, F. S. Menezes, G. G. Leitao, A. S. Reis, T. C. Dos Santos, and C. S. Coube, "Screening of Brazilian plant extracts for antioxidant activity by use of DPPH free radical method," Phytotherapy Research, vol. 15, pp. 127-130, 2011.

[39] B. H. Havsteen, "The biochemistry and medical significance of flavonoids," Pharmacology \& Therapeutics, vol. 96, no. 2-3, pp. 67-202, 2002.

[40] J. Fotie, "The antiprotozoan potential of flavonoids: a review," Pharmacognosy Reviews, vol. 2, no. 3, pp. 6-19, 2008.

[41] A. Aberoumand and S. S. Deokule, "Comparison of phenolic compounds of some edible plants of Iran and India," Pakistan Journal of Nutrition, vol. 7, no. 4, pp. 582-585, 2008. 